\title{
OPTIMALAUS SKAITMENINIO RELJEFO MODELIO SUDARYMO TECHNOLOGIJOS TOBULINIMAS
}

\author{
Algirdas Kumetaitis, Aušra Kumetaitienė \\ Geodezijos ir kadastro katedra, Vilniaus Gedimino technikos universitetas, \\ Sauletekio al. 11, LT-10223 Vilnius-40, Lietuva, \\ el.paštas: Algirdas.Kumetaitis@bite.lt, $\underline{\text { A.Kumetaitiene@ivpk.lt }}$
}

Iteikta 20041214 , priimta 20050406

\begin{abstract}
Santrauka. Šiame darbe tiriama skaitmeninio reljefo modelio tikslumo priklausomybè nuo reljefo tipo ir pasirinkto paviršiaus modeliavimo metodo. Rekomenduojama metodika paviršiui skaidyti i skirtingas reljefo kategorijas. Šis paviršiaus skaidymas i skirtingas reljefo kategorijas grindžiamas reljefo raižytumo skaičiavimu keliais etapais, įvertinant šlaitų nuolydžius, nuolydžių kryptis, reljefo kintamumą pasirinktoje teritorijoje. Atliktas tyrimas ieškant optimalaus paviršiaus modeliavimo metodo kiekvienai reljefo kategorijai. Palygintas reljefo modelių, gautu skirtingais paviršiaus modeliavimo metodais, tikslumas. Išskirti tiksliausi paviršiaus modeliavimo algoritmai. Pateikiama reljefo modelio standartinio nuokrypio preliminaraus vertinimo metodika.
\end{abstract}

Raktažodžiai: skaitmeninis reljefo modelis, fizinio žemės paviršiaus modelis, aplinkos modeliavimas.

\section{Ivadas}

Dabar reljefui ir kitiems ištisiniams paviršiams modeliuoti yra naudojamos dvi pagrindinès SRM duomenų struktūros: trikampių tinklas (TIN) ir taisyklingas stačiakampių tinklas [1]. Reikalavimai skaitmeniniam reljefo modeliui priklauso nuo modelio paskirties [2, 3]. Sudarytas reljefo modelis tiriamas pagal 1:10 000 mastelio žemèlapio aukščio taškus. Analizuojant gautus rezultatus išrenkama tinkamiausia reljefo modeliavimo metodika.

Optimaliam SRM sudaryti taikant skritingus paviršiaus modeliavimo metodus buvo parengta metodika, susidedanti iš šių etapų:

- Pagal išmatuotus aukščiu taškus paprastojo krigingo metodu skaičiuojamas skaitmeninis reljefo modelis [4].

- Atliekama pasirinktos teritorijos paviršiaus analizė [5], nustatomos paviršiaus charakteristikos [6], paviršius suskirstomas $\mathfrak{i}$ teritorijas pagal skirtingas geomorfologines savybes.

- Analizuojant skirtingais metodais sudarytu reljefo modelių standartinius nuokrypius [7], kiekvienai teritorijai išrenkamas tinkamiausias paviršiaus modeliavimo metodas.

- Skaičiuojamas bendras paviršiaus modelis, sujungiant skirtingais metodais apskaičiuotus pavieniu paviršiaus teritorijų skaitmeninius reljefo modelius.

\section{Metodikos etapų aprašymas}

Pirmuoju etapu analizuojami turimi išmatuoti paviršiaus taškai ir atrenkami taškai, kurie bus naudojami paviršiui modeliuoti, taip pat taškai, naudotini skaitmeninio paviršiaus modelio kontrolei. Atliktas tyrimas [8] parode, kad geriausi skaitmeninio paviršiaus modeliavimo rezultatai pasiekiami modeliavimui naudojant $80 \%$ paviršiaus taškų ir $20 \%$ paviršiaus taškų kontrolei. Kontrolei teritoriniu principu atrenkamas kas penktas paviršiaus taškas. Kiti taškai yra naudojami paviršiui modeliuoti. Sudarytas paviršiaus modelis yra kontroliuojamas ir tikslinamas [9], naudojant atrinktus taškus.

Antruoju etapu atliekama paviršiaus geomorfologinè analizè:

1. Skaičiuojamos sudaryto paviršiaus modelio šlaitų nuolydžių kryptys.

Skaitmeninis paviršius pagal nuolydžio krypti yra skirstomas i 9 kategorijas (1 pav.): šiaurès, šiaurès rytu, rytų, pietryčiu, pietu, pietvakariu, vakaru, šiaurès vakaru krypčiu ir teritorijas horizontaliu paviršiumi. Skaitmeninis šlaitų krypčių modelis šioje metodikoje naudojamas kaip pagalbinè priemonè reljefo raižytumui ivertinti.

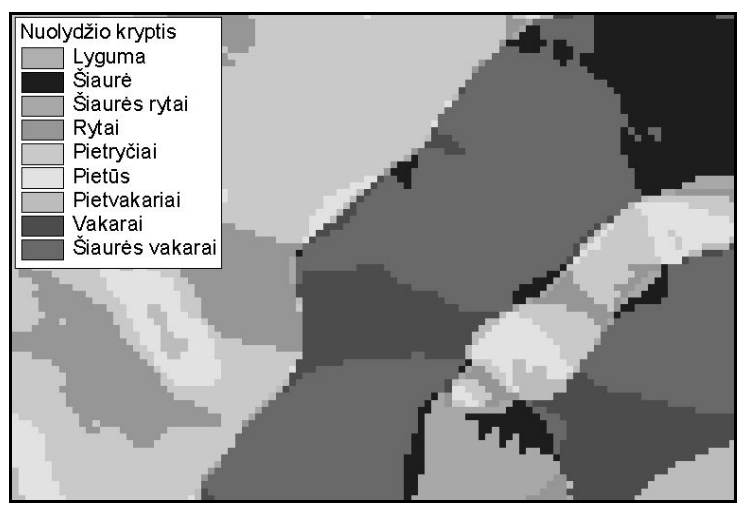

1 pav. Šlaitų krypčių sluoksnis

Fig 1. Layer of slopes directions 


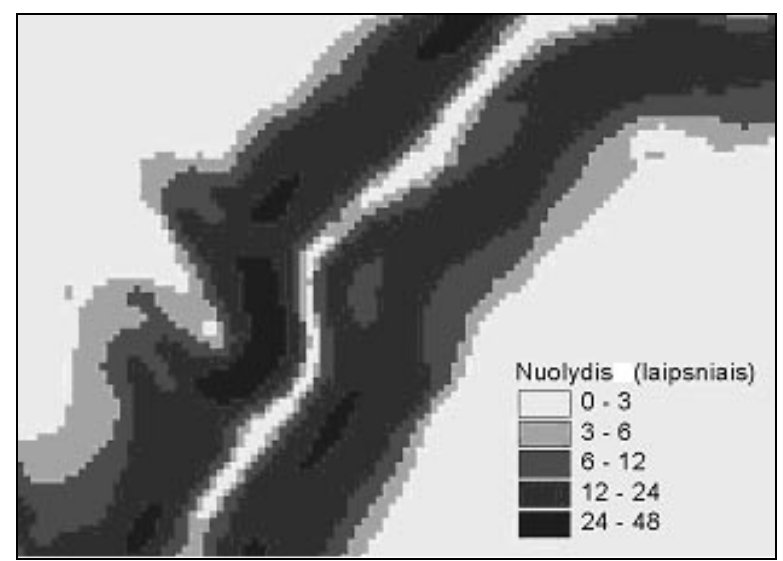

2 pav. Reljefo nuolydžiai

Fig 2. Relief inclinations

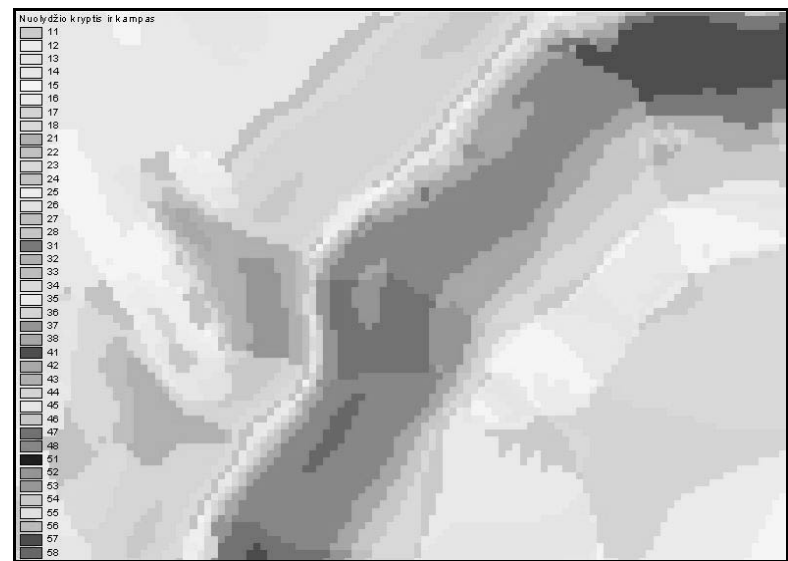

3 pav. Šlaitų krypčių ir nuolydžių sluoksnių sankirta

Fig 3. Intersection of layers of slopes directions and inclinations

2. Skaičiuojami nuolydžių dydžiai. Atlikti tyrimai parodè, kad didžiausios reljefo modelio paklaidos kaupiasi teritorijų stačiais šlaitais regionuose. Todèl svarbu išskirti teritorijas, kurių nuolydžiai skirtingi, kad vèliau galètume ịvertinti jų ịtaką modelio tikslumui kartu su reljefo kitimo duomenimis. Erdvinei sankirtai supaprastinti nagrinejjama teritorija pagal nuolydžio reikšmę skirstoma i 5 kategorijas (2 pav.).

3. Skaičiuojama šlaitų krypčių ir nuolydžių sluoksnių sankirta (3 pav.). Gaunamas žemėlapis, kuriame matomas nuolydžio kampo ir šlaito krypties kitimas. Pirmasis nuolydžio krypties ir nuolydžio kampo sankirtos geokodo skaičius rodo nuolydžio dydi (2 pav.), antrasis skaičius - nuolydžio krypti (1 pav.).

4. Pagal šlaitų krypčių ir nuolydžių sluoksnių sankirtą skaičiuojamas santykinis reljefo kintamumas. Jis randamas skaičiuojant, kiek pasirinktame plote yra skirtingų reikšmių tinklinio modelio ląstelių, palyginti su visu modeliuojamu plotu:

$$
R=\frac{n}{k} \times 100,
$$

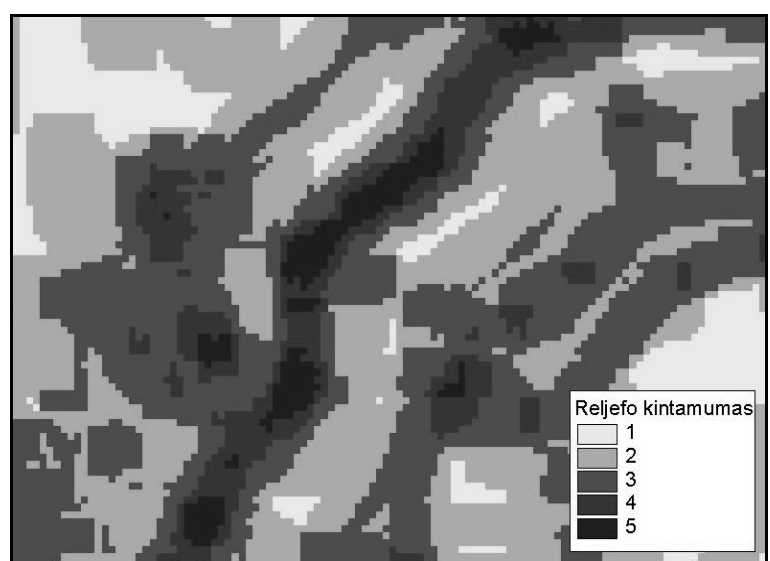

4 pav. Reljefo santykinis kintamumas

Fig 4. Relative variability of relief

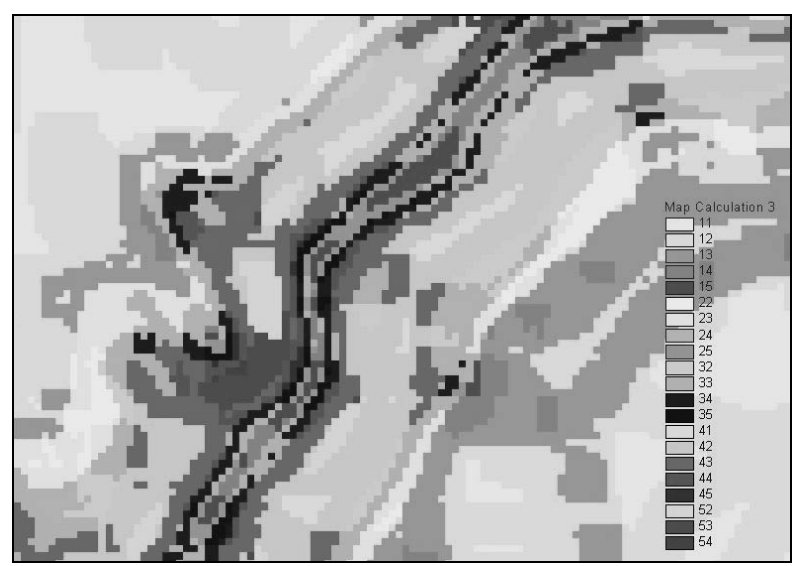

5 pav. Reljefo santykinio kintamumo ir nuolydžių sluoksnių sankirta

Fig 5. Intersection of layers of relief relative variability and inclinations

čia $R$ - santykinis reljefo kintamumas, $k$ - skirtingu paviršiaus reikšmių skaičius tinkliniame modelyje, $n-$ analizuojamų ląstelių skaičius, $n=7 \times 7=49$. Tokio dydžio analizuojamas paviršiaus ląstelių masyvas buvo pasirinktas eksperimentiškai, lyginant rezultatus, gautus taikant 5×5, 7×7, 9×9 ląstelių dydžio kvadratus. Reljefo kintamumas skirstomas i kategorijas.

Santykinio kintamumo žemèlapis (4 pav.) rodo reljefo raižytumą, horizontaliuosius ir vertikaliuosius paviršiaus pokyčius.

5. Randama reljefo santykinio kintamumo ir nuolydžių sluoksnių sankirta (5 pav.).

Remdamiesi šia sankirta galime atlikti reljefo tyrimą ir patikrinti prielaida, kad paviršiaus modeliavimo metodai pranašesni, kai skirtingos modeliuojamo paviršiaus formos.

Šiam tikslui naudojami M 1:1000 stereofotogrametriškai išmatuoti taškų aukščiai. Taško aukščio matavimo ribinè paklaida gali siekti iki $30 \mathrm{~cm}$. Matavimams pasirinktas skirtingų reljefo tipu Šeškinès ozo fragmentas. 


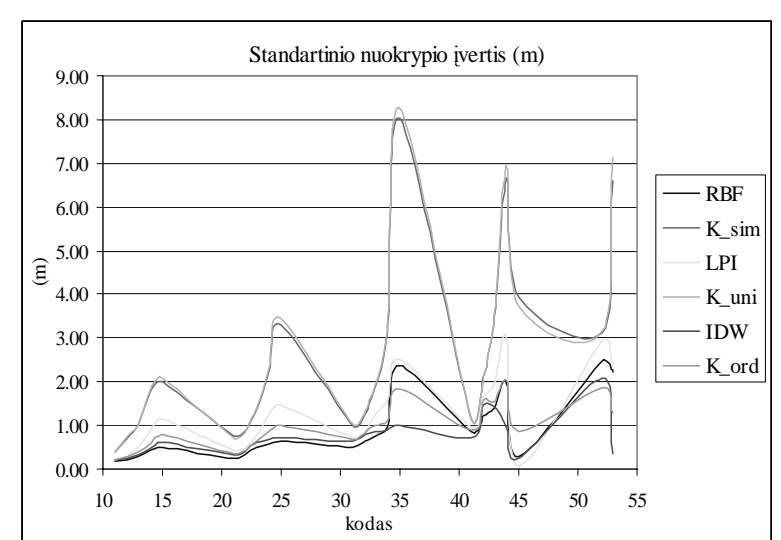

6 pav. Reljefo modelių standartinio nuokrypio įverčiu pasiskirstymas reljefo kategorijose

Fig 6. Distribution of DEM standard deviations in different relief categories

Kadangi labai svarbu tiksliai įvertinti paviršiaus modeliavimo metodų tikslumą, SRM sudaryti naudojama daugiau kaip 1700 taškų, tarp kurių vidutinis atstumas yra 30 m, o daugiau kaip 3800 taškų aukščių reikšmių yra naudojamos sudarytų reljefo modelių kontrolei.

Skaitmeninis reljefo modelis buvo sudarytas keliais paviršiaus modeliavimo metodais (apskritimo spindulio funkcijos metodu, supaprastintojo, universaliojo, paprastojo krigingo metodais, lokaliosios polinominès interpoliacijos metodu, svoriniu metodu). Pagal kontrolinius taškus įvertinamas sudarytų $S R M$ tikslumas. Pasirenkamas paprastuoju krigingo metodu sudarytas $S R M$. Pasirenkamas paprastasis krigingo metodas, nes atliktieji eksperimentai parodè, kad tokiu būdu sudaryti $S R M$ geriausiai atkartoja natūralią reljefo formą $[5,8]$. Pagal anksčiau aprašytą metodiką $S R M$ yra apdorojamas bei skaičiuojama reljefo santykinio kintamumo ir nuolydžių sluoksnių sankirta. Pagal šią sankirtą randamos visų turimų reljefo modelių paklaidos kiekvienoje reljefo suskirstymo klasėje (6 pav.).

Iš lentelèje pateiktų skaičiavimų rezultatų matome, kad nè vienas reljefo modeliavimo metodas neturi pranašumo visose reljefo kategorijose. I skiltyje pateikti paviršiaus modeliavimo metodai, kuriuos taikant gauti geriausieji rezultatai, o II skiltyje - metodai, kuriu rezultatai prastesni. Šie rezultatai dar gali būti pakoreguoti, tikslinant paviršiaus modeliavimo parametrus kiekvienai reljefo kategorijai atskirai. Iš sudarytu SRM pagal gautus tikslumo skaičiavimo rezultatus yra skaičiuojamas bendras didžiausio tikslumo $S R M$. Tose vietose, kur jungiasi skirtingais metodais sudaryti $S R M$, taikant modelių sankirtą apskaičiuojamos vidutinès paviršiaus modelio reikšmès. Geriausi SRM jungimo rezultatai pasiekti taikant svorini metodą, kai SRM sanklotos juostos plotis lygus šešių tinklinio modelio ląstelių skersmeniui.

Skirtingų paviršiaus modeliavimo metodų tikslumo įvertinimas

Estimation of different interpolation methods for surface modelling

\begin{tabular}{|c|c|c|c|c|c|c|c|c|c|c|}
\hline \multirow{3}{*}{$\begin{array}{c}\text { Taškuz } \\
\text { skaičius }\end{array}$} & & \multirow{2}{*}{\multicolumn{6}{|c|}{ Standartinio nuokrypio įvertis (m) }} & \multirow{3}{*}{$\begin{array}{l}\text { Min. } \\
\text { reikšmė }\end{array}$} & \multicolumn{2}{|c|}{ Tiksliausieji metodai } \\
\hline & & & & & & & & & \multirow{2}{*}{$\begin{array}{c}\text { Pirmasis } \\
\text { I }\end{array}$} & \multirow{2}{*}{$\begin{array}{c}\text { Antrasis } \\
\text { II }\end{array}$} \\
\hline & Kodas & RBF & K_sim & LPI & K_uni & IDW & K_ord & & & \\
\hline 136 & 11 & 0,19 & 0,41 & 0,21 & 0,40 & 0,21 & 0,22 & 0,19 & RBF & IDW, LPI \\
\hline 554 & 12 & 0,23 & 0,72 & 0,29 & 0,74 & 0,27 & 0,28 & 0,23 & RBF & IDW \\
\hline 769 & 13 & 0,30 & 0,99 & 0,50 & 1,02 & 0,33 & 0,38 & 0,30 & RBF & IDW \\
\hline 139 & 14 & 0,44 & 1,74 & 0,87 & 1,79 & 0,46 & 0,56 & 0,44 & RBF & IDW \\
\hline 44 & 15 & 0,48 & 2,00 & 1,13 & 2,07 & 0,61 & 0,80 & 0,48 & RBF & IDW \\
\hline 40 & 21 & 0,26 & 0,74 & 0,42 & 0,73 & 0,33 & 0,36 & 0,26 & RBF & IDW \\
\hline 396 & 22 & 0,37 & 0,88 & 0,49 & 0,89 & 0,41 & 0,43 & 0,37 & RBF & IDW \\
\hline 607 & 23 & 0,49 & 1,37 & 0,77 & 1,39 & 0,61 & 0,65 & 0,49 & RBF & IDW \\
\hline 138 & 24 & 0,58 & 2,23 & 1,26 & 2,29 & 0,68 & 0,87 & 0,58 & RBF & IDW \\
\hline 41 & 25 & 0,64 & 3,32 & 1,46 & 3,43 & 0,71 & 1,02 & 0,64 & RBF & IDW \\
\hline 69 & 31 & 0,49 & 0,99 & 0,72 & 1,05 & 0,65 & 0,68 & 0,49 & RBF & IDW \\
\hline 345 & 32 & 0,64 & 1,27 & 0,87 & 1,31 & 0,78 & 0,82 & 0,64 & RBF & IDW \\
\hline 356 & 33 & 0,76 & 1,92 & 1,25 & 1,94 & 0,85 & 1,01 & 0,76 & RBF & IDW \\
\hline 65 & 34 & 0,96 & 3,12 & 1,58 & 3,18 & 0,90 & 1,10 & 0,90 & IDW & RBF \\
\hline 15 & 35 & 2,38 & 8,03 & 2,52 & 8,26 & 1,01 & 1,84 & 1,01 & IDW & K_ord \\
\hline 11 & 41 & 0,85 & 1,14 & 0,95 & 1,15 & 0,70 & 0,89 & 0,70 & IDW & RBF \\
\hline 76 & 42 & 1,22 & 2,12 & 1,65 & 2,11 & 1,46 & 1,58 & 1,22 & RBF & IDW \\
\hline 57 & 43 & 1,41 & 3,33 & 1,92 & 3,35 & 1,43 & 1,56 & 1,41 & RBF & IDW \\
\hline 6 & 44 & 2,02 & 6,66 & 3,06 & 6,96 & 0,96 & 2,04 & 0,96 & IDW & RBF \\
\hline 2 & 45 & 0,28 & 3,93 & 0,08 & 3,75 & 0,25 & 0,85 & 0,08 & LPI & IDW \\
\hline 14 & 52 & 2,46 & 3,11 & 2,95 & 3,14 & 2,07 & 1,88 & 1,88 & K_ord & IDW \\
\hline 3 & 53 & 2,22 & 6,61 & 2,38 & 7,13 & 0,35 & 1,28 & 0,35 & IDW & K_ord \\
\hline 3884 & Viso & 0,89 & 2,57 & 1,24 & 2,64 & 0,73 & 0,96 & 0,65 & RBF & IDW \\
\hline
\end{tabular}




\begin{tabular}{|l|l|l|l|l|}
\hline $\mathrm{h}_{11}$ & $\mathrm{~h}_{12}$ & $\mathrm{~h}_{13}$ & $\mathrm{~h}_{14}$ & $\mathrm{~h}_{15}$ \\
\hline $\mathrm{h}_{21}$ & $\mathrm{~h}_{22}$ & $\mathrm{~h}_{23}$ & $\mathrm{~h}_{24}$ & $\mathrm{~h}_{25}$ \\
\hline $\mathrm{h}_{31}$ & $\mathrm{~h}_{32}$ & $\mathrm{~h}_{33}$ & $\mathrm{~h}_{34}$ & $\mathrm{~h}_{35}$ \\
\hline $\mathrm{h}_{41}$ & $\mathrm{~h}_{42}$ & $\mathrm{~h}_{43}$ & $\mathrm{~h}_{44}$ & $\mathrm{~h}_{45}$ \\
\hline $\mathrm{h}_{51}$ & $\mathrm{~h}_{52}$ & $\mathrm{~h}_{53}$ & $\mathrm{~h}_{54}$ & $\mathrm{~h}_{55}$ \\
\hline
\end{tabular}

7 pav. Tinklinio modelio gretimų ląsteliu aukščiu skirtumo skaičiavimas

Fig 7. Height differences calculation using neighborhood cells in grid model

Sudètingo reljefo vietovèse gali būti sunku realizuoti ši uždavini. Todèl reljefui klasifikuoti tokiose vietovèse siūlome vietoje reljefo nuolydžio parametro taikyti gretimu tinklinio modelio ląsteliu aukščiu vidutinius skirtumus (7 pav.). Taip pat šie sluoksniai gali būti naudojami vizualizuojant fizinio žemès paviršiaus modeli.

Tokiu atveju labiau tinka reljefą klasifikuoti apibendrintai, skaičiuojant ne gretimu, o tolimesniu ląstelių aukščių skirtumus pagal šią formulę:

$$
\Delta h_{i j}=\frac{4 h_{i j}-h_{(i-2) j}-h_{(i+2) j}-h_{i(j-2)}-h_{i(j+2)}}{4}
$$

čia $\Delta h_{i j}$ - gretimų ląstelių aukščių skirtumas, $h_{i j}$ tinklinio modelio ląstelès aukštis.

Atlikti eksperimentai parodè, kad skaitmeninio reljefo modelio klasifikavimas, taikant vidutinius gretimu tinklinio modelio ląstelių aukščiu skirtumus, labiau tinka reljefo modeliavimo metodui parinkti, nes gaunami labiau apibendrinti rezultatai. Paviršius yra suskirstomas i klases pagal reljefo tipa, tačiau išvengiama per smulkaus klasifikavimo, kuris apsunkina reljefo modeliavimo procesą, nes kiekvienai reljefo modelio klasei gali būti taikomas kitas reljefo modeliavimo metodas arba skirtingi reljefo modeliavimo parametrai.

Pagal aukščiu skirtumus sudarytas paviršius rodo pokyčius reljefo modelyje ( 8 pav.).

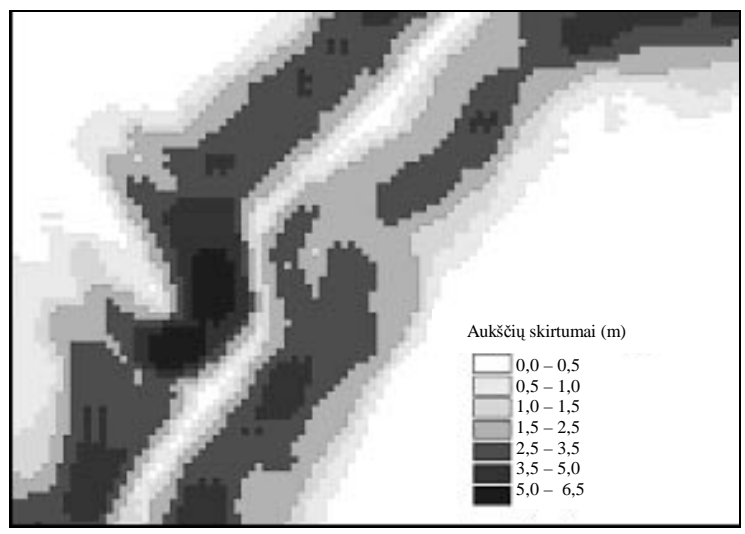

8 pav. Reljefo klasifikavimas, taikant gretimų ląstelių aukščiu skirtumus

Fig 8. Relief clasification applying height differences between neighbourhood cells

Skaičiavimus supaprastinti, gretimų ląstelių aukščių skirtumus gauti galima pagal apskaičiuotus nuolydžius, taikant autoriaus išvestą formulę:

$$
\Delta h=i \times\left(\frac{i d}{25 \sqrt{2}}-k\right),
$$

čia $i$ - paviršiaus nuolydis tam tikrame taške, $d$ - tinklinio modelio ląstelès skersmuo, $k$ - empirinis pataisos koeficientas. Tyrimai parode, kad kai tinklinio modelio ląstelès skersmuo $5 \mathrm{~m}$ (9 pav.), tiksliausi rezultatai pasiekiami, esant $k=0,026$. Tuomet esant iki 10 laipsniu nuolydžiui (8 pav.), $\Delta h$ paklaida neviršija pradiniu duomenų tikslumo $(0,3 \mathrm{~m})$, o esant statesniam nuolydžiui, siekia $0,7 \mathrm{~m}$. Skaitmeninio reljefo modelio tyrimo rezultatas pateikiamas 10 pav. $H$ - reljefo paviršiaus profilio linija, apačioje pateikiami nuolydžio kitimo grafikai laipsniais ir procentais.

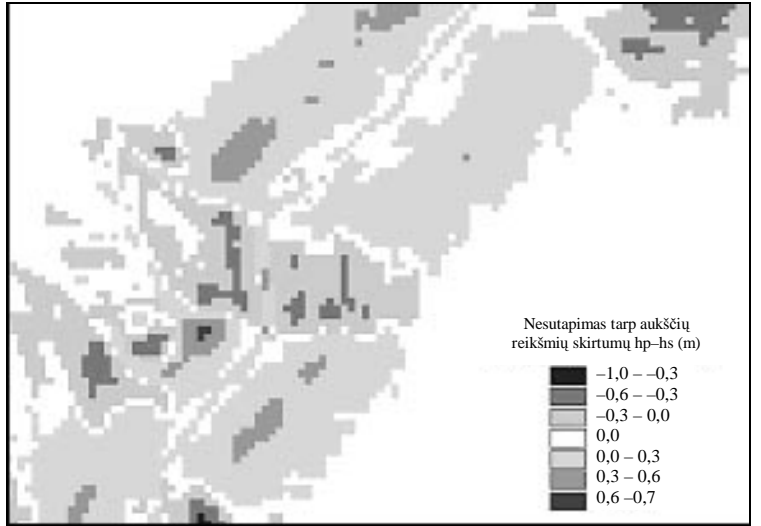

9 pav. Skirtumai tarp išmatuotų ir prognozuojamų gretimu ląstelių reikšmiu

Fig 9. Differences between calculated and predicted values of neighbourhood cells 


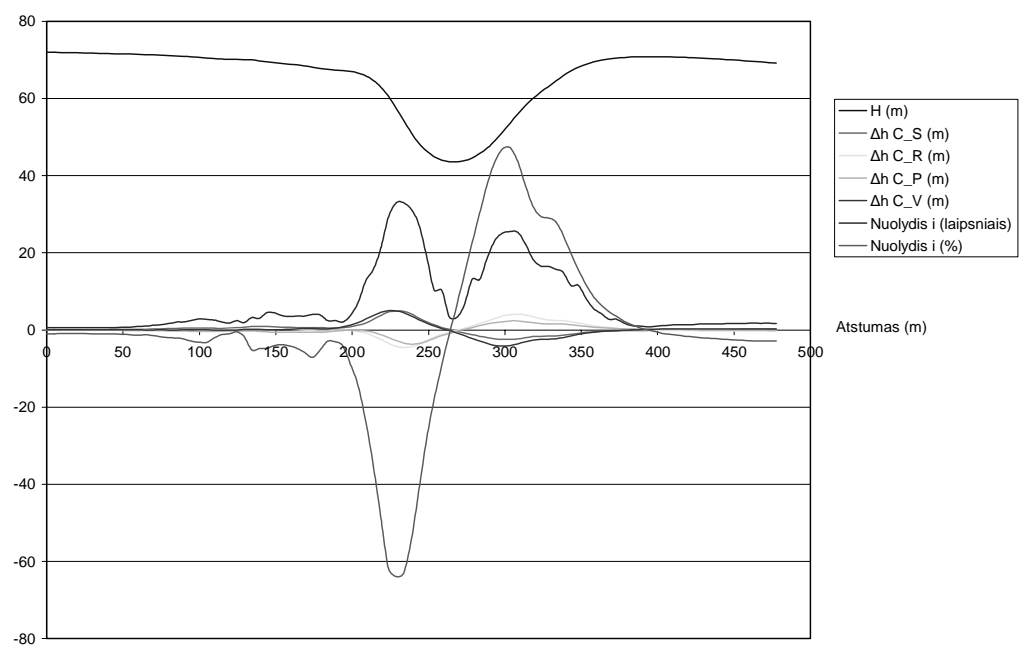

10 pav. Reljefo modelio profilio aukščių skirtumų ir nuolydžio grafikas

Fig 10. Chart of DEM profile, height differences and slope

\section{Išvados}

Lietuvos teritorijos reljefo modelio tikslumas varijuoja pagal reljefo tipą.

Autorius parengè metodiką, skirtą optimaliam SRM, sudaryti taikant skirtingus paviršiaus modeliavimo metodus. Tiriamos teritorijos modeliavimas buvo atliktas šiais metodais: apskritimo spindulio funkcijos; supaprastinto krigingo; universaliojo krigingo; paprastojo krigingo; lokaliosios polinominès interpoliacijos; svoriniu.

Tyrimo rezultatai parodè, kad nè vienas reljefo modeliavimo metodas neturi pranašumo visose reljefo kategorijose, bet padejo rasti optimalius metodus kiekvienai reljefo formai.

Modeliuojant paviršiu stačiakampių tinklo modeliu, didžiausias tikslumas pasiektas sudarant SRM mūsu patobulintu krigingo metodu, taikant apskaičiuotus pataisos koeficientus.

Sudaryta metodika, kurią taikant didesnis reljefo modeliavimo tikslumas pasiekiamas skirstant paviršiu pagal reljefo i̇vairovę, tad kiekvienai šiu teritorijų pagal siūlomą paviršiaus analizès metodiką galima parinkti tinkamiausią paviršiaus modeliavimo metodą.

\section{Literatūra}

1. Arc/Info, Surface Modelling with TIN ${ }^{\mathrm{TM}}$ User's Guide. Environmental Systems Research Institute (ESRI), Inc., Redlands, CA, 1992.

2. Dẻnas, Ž.; Kumetaitis, A.; Šliaupa, S.; Zakarevičius, A. Digital Model of Relief and Application of GIS for Surface Erosion Model of Lithuania. In: $33^{\text {rd }}$ Symposium International „Recent Developments in Environmental Protection“, September 25-26, 2003, Vilnius, VGTU.

3. Defourny, P.; Hecquet, G.; Philippart, T. Digital terrain modelling - accuracy assessment hydrological simulation sensitivity (Ch. 7). In: Lowell K., Jaton A. (eds.). Spatial Accuracy Assessment - Land Information Uncertainty in
Natural Resources. Chelsea, MI: Ann Arbor Press, 1999, p. 61-70.

4. Wilson, J. P.; Gallant, J. C. Terrain analysis - Principles, Applications. Chichester UK \& NY, Wiley, 2000. 479 p.

5. Fisher, P. F. Improved modeling of elevation error with geostatistics. Geoinformatica, 2 (3), 1998, p. 215-233.

6. Brabyn, L. K. Classification of macro landforms using GIS. ITC Journal, 1, 1997, p. 26-40.

7. Davis, J. Statistics and data analysis in geology. New York: Wiley, 1986.

8. Kumetaitis, A. Making and developing the digital elevation models by geostatistical methods. Geodesy and Cartography (Geodezija ir kartografija), Vol XXX, No 1. Vilnius: Technika, 2004, p. 29-34 (in Lithuanian).

9. Rees, W. G. The accuracy of digital elevation models interpolated to higher resolutions. International Journal of Remote Sensing, 21 (1), 2000, p. 7-20.

Algirdas KUMETAITIS. Engineer. UAB „Bite GSM“, Žemaitè g. 15, LT-03504 Vilnius $(\mathrm{Ph}+37069900308,+370$ 699 23308), e-mail: taku@bite.lt.

A graduate of Vilnius Gediminas Technical University (BSc 1998, MSc, 2000)

Research interests: GIS, digital elevation modelling.

Aušra KUMETAITIENĖ. Assistant. Vilnius Gediminas Technical University. Dept of Geodesy and Cadastre. Sauletekio al. 11, LT-10223 Vilnius-40, Lithuania

$(\mathrm{Ph}+3705$ 2744703, Fax 3705 2744731).

Chief specialist. Information Society Development Committee under the Government of the Republic of Lithuania. Electronic Services and Innovations Division. Gedimino pr. 56, LT-01110 Vilnius, Lithuania ( $\mathrm{Ph}+3705$ 2665187, Fax 3705 2665180), e-mail: a.kumetaitiene@ivpk.lt.

A graduate of Vilnius Gediminas Technical University (BSc 1998, MSc, 2000). Courses in Norway (1997). Research interests: digital elevation modelling, digital photogrammetry, GIS and multiparameter decision analysis. 